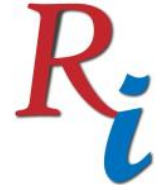

Asia Proceedings of Social Sciences

(APSS)

www.readersinsight.net/APSS

\title{
USING LMS FOR BEYOND SCHOOL CONNECTIVITY AND SELF- REGULATION OF LEARNING: A CASE STUDY OF EDOPIA
}

\author{
Aruba Sundus Malik*
}

Department of Education

Fatima Jinnah Women University

Pakistan

arubamalik.as@gmail.com

\section{Farhana Khurshid}

Department of Education

Fatima Jinnah Women University

Pakistan

f.khurshid@fjwu.edu.pk

*Corresponding author's Email: arubamalik.as@gmail.com

Peer-review under responsibility of 4th Asia International Multidisciplinary Conference 2020 Scientific Committee http://connectingasia.org/scientific-committee/ (C) 2020 Published by Readers Insight Publisher, Office \# 6, First Floor, A \& K Plaza, Near D Watson, F-10 Markaz, Islamabad. Pakistan, editor@readersinsight.net This is an open access article under the CC BY-NC-ND license (http://creativecommons.org/licenses/by-nc-nd/4.0/). 


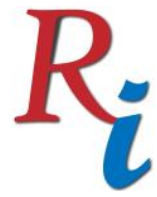

Asia Proceedings of Social Sciences

(APSS)

www.readersinsight.net/APSS

\section{A b s t r a c t}

Self- regulated learning skills (SRL) are deemed essential for survival in the 21 st century and should be developed among students by providing the opportunities of beyond school connectivity (Uz \& Uzun, 2018; Broadbent, 2017). Current study is a case study of Edopia School, utilizing Learning Management System (LMS) and face-to-face interaction in an aim to develop SRL skills among students. Therefore, this research was conducted to find out the level of the SRL skills among the students and record their views about the provision of LMS for beyond school connectivity and its role in the development of SRL Skills. Motivated Strategies for Learning Questionnaire (MSLQ) was administered to assess the level of SRL skills followed by focus group discussions to gather views of the students. It was found that LMS helped the learners in developing SRL skills with the mean score of 5.45, 5.7 and 5.5 on three components of MSLQ. During focus group discussion students highlighted the learning environment of the school, student- teacher ratio and parental involvement as motivating factors for the development of SRL skills.

Keywords: Self-Regulation, Learning Management System, Edopia, MSLQ, Elementary Students

\section{Rese a r ch H i g h I igh s}

The current research study highlights the following:

- Organizational LMS are an important tool to build beyond school connections with the learners.

- Self-regulated learning skills develop among students as a result of motivation and sense of responsibility given by the school and parents.

- Parental involvement is crucial for the learners to be independent.

- Teacher-student ratio has a positive impact on learners' self- regulated skills.

- Designing activities for the learners like "free inquiry weeks" give students a chance to practice self- regulated learning skills.

\section{Research Objectives}

The objectives of the current study included the following:

- To know the level of self- regulated learning of the students experiencing blended learning at secondary level.

- To record the views of students regarding beyond school connectivity by the utilization of LMS. 


\section{Significance of the study}

Current case study focused on the development of self- regulated learning skills through the learning management system(LMS). This study identified views of the students with respect to the beyond school connectivity and their self- regulated learning strategies. Therefore, the current study has added to the body of knowledge and can be significant for the following:

- The study will contribute to the scholars who are interested in the field of blended learning and self- regulation. A number of research studies have been conducted in the area but the current study provides its importance on elementary level in Pakistan.

- The study is significant for the teachers to develop strong student-teacher relationships and motivate learners.

- The study is significant for the young learners to help them believe in themselves and their potential to be effective learners.

\section{Methodology}

Teddlie and Tashakkori (2012) argue that the paradigm position facilitates the researcher in making important decisions about the methodology of the research. Therefore, the third methodological movement was considered for the current study, because the research objectives and questions called out for a pragmatist approach and collection of data through different procedures, highlighted by two different paradigms, qualitative and quantitative.

\section{Quantitative Data}

The first research question focused on the level of self- regulated learning skills of the students and incorporated a quantitative data collection process. The quantitative data was collected through the administration of MSLQ-Motivated Strategies for Learning Questionnaire (Pintrich, Smith, Gracia \& Mckeachie, 1991). It consists of 81 items and is based on the conceptual framework for self- regulation and motivation(Pintrich, 2004; Pintrich, 1991).

\section{Qualitative Data}

The second question of the current study required in-depth data and information and was subjective in nature. For collection of data, focus group discussions were conducted with participant students. The questions of the focus group discussions were designed in the light of MSLQ and some were generated during the discussion. 


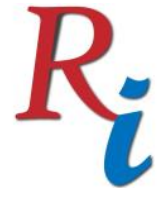

\section{Results}

The results of quantitative data collected through MSLQ were presented according to the components of the Pintrich Model using three important components; Motivation, learning strategies and resource management strategies(Pintrich, 1991). The participants scored an average mean score of 5.48 on the scales of motivation with highest mean score on expectancy component with 5.75, lowest on affective component with 5.3, and 5.4 on value component. The participants showed a mean score of 5.54 on learning strategies component with the highest score on Critical thinking skills with 5.8 and lowest on cognitive and meta-cognitive scale with 5.28.Furthermore, on the component of resource management strategies, the participants scored a mean score of 5.7 with highest mean score on the sub-component of effort regulation and lowest on 5.43 which indicates that the participants are practicing the selfregulated learning strategies.

The quantitative data was supported by qualitative data where the students reported that the failure or success depends on their own efforts. The qualitative data was analyzed through deductive thematic analysis and few emergent themes that emerged during the coding process. The learners also reported that the community- based operation in the school and on the learning management system keeps them updated and alert with deadlines and important tasks.

\section{Findings}

The major finding of the current research study are listed below:

\section{Beyond-school Connectivity:}

Beyond-school connectivity with the school, teachers, peers and administration provided by Edopia school through customized organizational LMS was found to be effective for the learning of the students and assisting them to keep on track of the learning.

\section{School Environment:}

The flexible school environment, teacher- student ratio and community based operation was found to boost the morale of the learners to self- regulate.

\section{Parental Support:}

The participants highlighted the fact that parental involvement and their belief in the learners, contributed in making them take charge and responsibility of their own learning. 
Asia Proceedings of Social Sciences

(APSS)

www.readersinsight.net/APSS

\section{Acknowledgement}

I present my sincere gratitude to my supervisor, Dr. Farhana Khusrhid for her sincerity, valuable supervision, timely feedback, constant support, fruitful counselling sessions and motivation. She has always been a source of inspiration. Thank you!

\section{References}

Broadbent, J. (2017). Comparing online and blended learner's self-regulated learning strategies and academic performance. Internet and higher education. 33, 2432. Doi: https://doi.org/10.1016/j.iheduc.2017.01.004.

ISTE. (2019.). Standards for Educators. Retrieved March 7, 2019, from https://www.iste.org/standards/for-educators.

Pintrich, P. R., Smith, D. A. F., Garcia, T., \& McKeachie, W. J. (1991). A manual for the use of the Motivated Strategies for Learning Questionnaire (MSLQ) (Technical Report No. 91-B-004), Ann Arbor, MI: University of Michigan, National Center for Research to Improve Postsecondary Teaching and Learning.

Pintrich, P.R. (2004). A conceptual framework for assessing motivation and self-regulated learning in college students. Educational Psychology Review. 16(4). 385-407.

Teddlie, C., \& Tashakkori, A. (2012). Common "Core" Characteristics of Mixed Methods Research. American Behavioral Scientist, 56(6), 774-788. Doi: $10.1177 / 0002764211433795$

Uz, R., Uzun, A. (2018). The influence of blended learning environment on self-regulated and self-directed learning skills of learners. European journal of educational research. 7(4). 877-886. 